Supporting information for:

\title{
Metabolic Labeling with an Alkyne-modified Isoprenoid Analog Facilitates Imaging and Quantification of the Prenylome in Cells
}

Charuta C. Palsuledesai, ${ }^{1, a}$ Joshua D. Ochocki, ${ }^{1, a}$ Michelle Henderson, ${ }^{1}$ Yen-Chih

Wang, ${ }^{1}$ Janel K. Warmka, ${ }^{2}$ Dustin S. Chernick, ${ }^{3}$ Elizabeth V. Wattenberg, ${ }^{2}$ Ling Li, ${ }^{3}$ Edgar A. Arriaga, ${ }^{1}$ and Mark D. Distefano. ${ }^{{ }^{*}}$

${ }^{a}$ These authors have equal contribution to the work.

${ }^{1}$ Department of Chemistry, University of Minnesota, Minneapolis, MN 55455 (USA)

${ }^{2}$ Division of Environmental Health Sciences, University of Minnesota, Minneapolis, MN 55455 (USA)

${ }^{3}$ Department of Experimental and Clinical Pharmacology, University of Minnesota, Minneapolis, MN 55455 (USA)

${ }^{*}$ Corresponding Author: Mark D. Distefano,diste001@umn.edu 


\section{Experimental methods}

Materials

HeLa cells were the generous gift of Dr. Audrey Minden (Department of Chemical Biology, Rutgers University); all other cell lines were purchased from ATCC. $100 \mathrm{~mm}$ tissue culture treated dishes were from Corning Scientific. Petri dishes $(35 \mathrm{~mm})$ fitted with microwells $(14 \mathrm{~mm})$ and a No. 1.5 coverglass were from MatTek Corporation. Tissue culture treated 6-well multiwell plates and $5 \mathrm{~mL}$ polystyrene round bottom tubes $(12 \times 75 \mathrm{~mm})$ were from BD Biosciences. DMEM (Dulbecco's Modified Eagle Medium), ER Tracker Red, wheat germ agglutinin-AlexaFluor 594 conjugate, Lipofectamine 2000, Stealth ATG7 RNAi, Stealth RNAi Universal Negative Control, Opti-MEM, neurobasal medium, B27 supplement, Fetal bovine serum (FBS) and glutamine were from Invitrogen. 3-PEHPC was a generous gift from Dr. David F. Wiemer. GGTI-286 was purchased from CalBioChem and L-744,832 was from Merck. $70 \mu \mathrm{m}$ cell strainers and SuperSignal West Pico Chemiluminescent Substrate were from ThermoFisher Scientific. Immobilon-P PVDF membranes were from Millipore, Anti-H-ras rabbit polyclonal and anti-ERK2 rabbit polyclonal antibodies were from Santa Cruz Biotechnology. Anti-rabbit IgG horseradish peroxidase-linked secondary antibody was from Cell Signaling. Vydac 218TP54 and 218TP1010 columns were used for analytical and preparative RP-HPLC, respectively. All analytical and preparative RP-HPLC solvents, water and $\mathrm{CH}_{3} \mathrm{CN}$, contained $0.10 \%$ TFA and were of HPLC grade. 5-Carboxyfluorescein succinimidyl ester and TAMRA-succinimidyl ester were from AnaSpec. All other reagents were from Sigma Aldrich, including benzonase nuclease (E1014) and protease inhibitor cocktail (P8340). 5-Fam-PEG-N $\mathrm{N}_{3}$ was synthesized as previously described. $^{1}$ 


\section{General cell culture}

Cells were seeded in culture dishes at the following densities prior to experimentation: HeLa 3.1 x $10^{4}$ cells $/ \mathrm{cm}^{2}$, MDCK $2.5 \times 10^{4}$ cells $/ \mathrm{cm}^{2}$, A549 $3.0 \times 10^{4}$ cells $/ \mathrm{cm}^{2}, \mathrm{NIH} / 3 T 32.5 \times 10^{4}$, MCF10A and MCF10A-HRas $3.3 \times 10^{4}$ cells $/ \mathrm{cm}^{2}$, COS-1 and -7 $2.0 \times 10^{4} \mathrm{cells} / \mathrm{cm}^{2}$, and L6 2.3 x $10^{3}$ cells $/ \mathrm{cm}^{2}$. HeLa, MDCK, NIH/3T3, COS-1, COS-7, and C2C12 were maintained in DMEM supplemented with 10\% FBS. A549 were maintained in RPMI supplemented with 10\% FBS. MCF10A and MCF10A H-Ras were maintained in DMEM/F12 supplemented with $5 \%$ horse serum, $0.5 \mu \mathrm{g} \mathrm{mL}^{-1}$ hydrocortisone, $10 \mu \mathrm{g} \mathrm{mL}^{-1}$ insulin, $20 \mathrm{ng} \mathrm{mL}^{-1} \mathrm{EGF}$, and $0.1 \mu \mathrm{g} \mathrm{mL}^{-1}$ cholera toxin. All cells were grown at $37^{\circ} \mathrm{C}$ with $5.0 \% \mathrm{CO}_{2}$.

Imaging Prenylated Proteins

HeLa, A549, MDCK, COS-7, or NIH/3T3 cells were seeded (see above for density) in $35 \mathrm{~mm}$ glass bottomed culture dishes and grown to approximately $50 \%$ confluence $(24 \mathrm{~h})$. The cells were rinsed twice with phosphate buffered saline (PBS), followed by the addition of $10 \mu \mathrm{M}$ C15Alk in $2 \mathrm{~mL}$ complete DMEM media. After $24 \mathrm{~h}$ probe incubation, the cells were rinsed twice with PBS, fixed with 4\% paraformaldehyde (PFA) in PBS for 10 min at RT, permeabilized with $0.1 \%$ Triton X-100 in PBS for 2 min at RT, and subsequently rinsed three times with PBS. The following reagents were added, in order, at the specified concentration (typically $300 \mathrm{uL}$ total volume in PBS): TAMRA-PEG- $\mathrm{N}_{3}$ or 5-Fam-PEG- $\mathrm{N}_{3}(0.1 \mathrm{mM})$, tris(2-carboxyethyl)phosphine (TCEP, $1 \mathrm{mM}$ ), tris[(1-benzyl-1H-1,2,3-triazol-4-yl)methyl] amine (TBTA, $0.2 \mathrm{mM}), \mathrm{CuSO}_{4}$ (1 $\mathrm{mM}$ ). Following $1 \mathrm{~h}$ incubation at RT, the cells were rinsed four times with PBS and Hoescht 34580 nuclear stain was added at a final concentration of $1 \mu \mathrm{g} \mathrm{mL}^{-1}$ for $10 \mathrm{~min}$. Additionally, for the colocalization experiments, ER Tracker Red (1 $\mu \mathrm{M}$ for $10 \mathrm{~min}$ ) or Wheat Germ Agglutinin conjugated to Alexa Fluor $594\left(5 \mu \mathrm{g} \mathrm{mL}^{-1}\right.$ for $\left.10 \mathrm{~min}\right)$ were added. The cells were rinsed twice with PBS and imaged using an Olympus FluoView FV1000 IX2 Inverted Confocal Microscope 
with a $60 \mathrm{X}$ objective. All the confocal images in Figure 2 were acquired under the identical microscope settings (including Laser source power, exposure time and PMT gain). Additionally, RGB settings used to prepare colored images in the Figure 2 are identical across each color.

\section{Quantifying the Prenylome}

Cells were seeded in 6-well culture dishes and grown to approximately 50-60\% confluence (24 h). Cell culture media was then supplemented with $25 \mu \mathrm{M}$ and cells were incubated for 18-24 h. Media from the cells was then replaced with $1 \mathrm{~mL}$ fresh media, followed by addition of 10-50 $\mu \mathrm{M}$ C15Alk (or as indicated). Cells were grown for $24 \mathrm{~h}$ in presence of C15Alk, unless otherwise

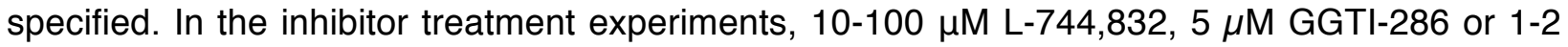
$\mathrm{mM}$ 3-PEHPC were added to cells $1 \mathrm{~h}$ prior to labeling with $10 \mu \mathrm{M}$ C15Alk. For competition experiments, $10-50 \mu \mathrm{M} \mathrm{FOH}, 10-50 \mu \mathrm{M}$ GGOH or $50-100 \mu \mathrm{M}$ mevalonolactone were added immediately following C15Alk addition. After incubation of C15Alk and/or inhibitors for various times (typically $24 \mathrm{~h}$ ), the cells were rinsed twice with PBS and trypsinized for $5 \mathrm{~min}$. After addition of $4 \mathrm{X}$ volume of media to inactivate trypsin, cells were transferred to micro-centrifuge tubes, and pelleted by centrifugation at $100 \times \mathrm{g}$ for $5 \mathrm{~min}$. The media was aspirated from the pellet and the cells were fixed with $4 \%$ paraformaldehyde in PBS for 10 min at RT, pelleted, and permeabilized with $0.1 \%$ Triton X-100 in PBS for 2 min at RT. After permeabilization, cells were pelleted and rinsed twice with $200 \mu \mathrm{L}$ PBS. Next, the following reagents (at the indicated final concentrations) were mixed immediately prior to use and $100 \mathrm{uL}$ total volume in PBS was added to each cell pellet: 5-Fam-PEG-N ${ }_{3}(0.5 \mathrm{mM})$, TCEP $(1 \mathrm{mM})$, TBTA $(0.2 \mathrm{mM}), \mathrm{CuSO}_{4}(1 \mathrm{mM})$. Following $1 \mathrm{~h}$ incubation at RT, the cells were pelleted, and rinsed three times with $200 \mu \mathrm{L}$ PBS. Cells were added to a $12 \times 75 \mathrm{~mm}$ test tube (1.5 mL in PBS) for flow cytometry analysis. A total of 10,000 events (cell counts) for each sample were analyzed using a BD FACSCalibur (BD Biosciences) or a BD Accuri C6 (BD Biosciences). 


\section{In-Gel Fluorescence}

HeLa cells were seeded in $60 \mathrm{~mm}$ or $100 \mathrm{~mm}$ culture dishes at $1.9 \times 10^{4}$ cells $/ \mathrm{cm}^{2}$ and grown for approximately $24 \mathrm{~h}$ (to approximately $50-60 \%$ confluence). Cell media were then supplemented with $25 \mu \mathrm{M}$ lovastatin (when indicated), cells were grown for 18-24 h. Cell media was then replaced with media containing $10 \mu \mathrm{M}$ C15Alk (unless specified otherwise) and cells were grown for $24 \mathrm{~h}$ (unless specified otherwise). Following this, the cells were rinsed twice with icecold PBS and scraped from the plate in 0.6-1.0 mL PBS using a teflon scraper. Cells were pelleted by centrifugation at $100 \times \mathrm{g}$ for $5 \mathrm{~min}$. After discarding the supernatant, $200-400 \mu \mathrm{L}$ of lysis buffer was added to each cell pellet. Lysis buffer consisted of PBS containing $1 \%$ SDS, protease inhibitor cocktail (per manufacturers protocols), benzonase (per manufacturers protocols), and 2.4 $\mu \mathrm{M}$ PMSF. Cells were lysed by sonicating with six cycles of 10 seconds on, 20 seconds off on ice. The concentration of protein in the lysate was determined using $D C^{\mathrm{TM}}$ protein assay (Bio-Rad). To $100 \mu \mathrm{g}\left(1 \mathrm{mg} \mathrm{mL}^{-1}\right.$ concentration) of HeLa lysate, CuAAC reagents were added at indicated final concentrations: $25 \mu \mathrm{M}$ TAMRA-PEG- $\mathrm{N}_{3}, 1 \mathrm{mM}$ TCEP, and $100 \mu \mathrm{M}$ TBTA. After vortexing, $1.0 \mathrm{mM} \mathrm{CuSO}_{4}$ (final concentration) was added, and the reaction was allowed to proceed at RT for $1 \mathrm{~h}$. Excess reagents were removed by protein precipitation with a ProteoExtract protein precipitation kit (Calbiochem), following manufacturers protocols. Protein pellets were dissolved in 1x Laemmli SDS-PAGE loading buffer and boiled for 6 min and 30-50 $\mu \mathrm{g}$ of protein samples were loaded onto $12 \%$ polyacrylamide gel. Gel was run at $120 \mathrm{~V}$ until dye front reached the bottom of the gel. For in-gel TAMRA fluorescence images, gels were scanned on a BioRad FX Molecular Imager. Gels were stained with Coomassie blue staining solution for total protein stain images. 


\section{In-Gel Fluorescence Densitometry}

Densitometry was performed using ImageJ. In brief, gel images in the TAMRA channel were converted into 8-bit mode and a region between $150 \mathrm{kDa}$ and $20 \mathrm{kDa}$ was selected for all the lanes. Lane profiles were plotted, bands were defined by drawing vertical lines, and the area under the curve was obtained for various bands in each lane. To remove the background, the area of the band in the DMSO control lane was subtracted from the area of the corresponding band in the other lanes. Proportions of total proteins present in various lanes were determined by densitometry of the total protein stain gel, and intensity of each lane in TAMRA channel was adjusted and normalized to this.

\section{Primary Astrocyte Preparation}

The brains were removed from $\mathrm{C} 3 \mathrm{H} / \mathrm{C} 57 \mathrm{BL} / 6$ mice pups at postnatal day $0-2$ and placed in $1 \mathrm{x}$ Hanks balanced salt solution (HBSS). Cortices and hippocampi were dissected out and meninges removed. The tissues were cut into $1 \mathrm{~mm}^{3}$ pieces with a sterile disposable scalpel, transferred to a conical tube with $1 \mathrm{x}$ trypsin in HBSS, and incubated in a $37^{\circ} \mathrm{C}$ water bath for 15 minutes. A stop solution, containing 4\% FBS and $0.2 \mathrm{mg} \mathrm{mL}^{-1}$ DNase I in HBSS, was added and the incubation extended for an additional 30 seconds at $37^{\circ} \mathrm{C}$. The tissue mixture was centrifuged at $200 \times \mathrm{g}$ for 5 minutes at RT and the supernatant was carefully aspirated from the tube. DMEM containing 10\% FBS was added to the cell pellet and the mixture was triturated 20 times with a fire-polished pasteur pipet to dissociate cells. The cell suspension was passed through a $100 \mu \mathrm{m}$ cell strainer to achieve single-cell suspension. Cells were then plated in T-75 flasks coated with poly-D-lysine, each plate was seeded with approximately 3-5 pups worth of glial cells. Cells were cultured at $37{ }^{\circ} \mathrm{C}$ with $5 \%$ of $\mathrm{CO}_{2}$, in DMEM containing $5 \% \mathrm{FBS}, 16 \mathrm{mM}$ Hepes Buffer, 1x non-essential amino acids, $2 \mathrm{mM}$ glutaMAX, $2.5 \mu \mathrm{g} \mathrm{mL} \mathrm{m}^{-1}$ aphotericin-B, and 50 
$\mu \mathrm{g} \mathrm{mL}^{-1}$ gentamicin. Media was changed on days 1, 2, 6, 14 and 21 post-plating to remove cellular debris. At this point, mixed glial/astrocyte cultures were trypsinized and approximately $0.5 \times 10^{6}$ cells were plated into each well of a poly-D-lysine $\left(0.1 \mathrm{mg} \mathrm{mL}^{-1}\right)$ coated 6 -well plate. For purifying astrocytes: 14 days after plating, microglial cells (attached on top of the astrocyte cell monolayer adhered to the culture plate) were harvested by shaking them off the astrocyte monolayer, and media was replaced on astrocyte culture. Seven days later, this process was performed again. At this time, astrocytes were passaged to a new T-75 flask and allowed to grow for 4 days, at which point they were shaken to remove any residual microglia and passaged again. Four days later, the astrocytes were passaged a third time and the total cell number and viability were determined with a hemocytometer by adding $20 \mu \mathrm{L}$ of cell suspension and $20 \mu \mathrm{L}$ of Trypan blue. Approximately $0.5 \times 10^{6}$ cells were plated into each well of a 6 -well plate, which had been previously coated with $0.1 \mathrm{mg} \mathrm{mL}^{-1}$ poly-D-lysine. After 3 days in culture, the astrocytes were subjected to metabolic labeling and quantification of the prenylome as described above.

\section{siRNA-Mediated Knockdowns}

BECN1 siRNA transfection was carried out according to manufacturer's instructions with the following modifications. BECN1 Silencer ${ }^{\circledR}$ Select Pre-designed siRNA (\#43907, ID s80166, Ambion, Foster City, CA) and Silencer $^{\circledR}$ Select Negative Control \#2 siRNA (\#43908, Ambion, Foster City, CA) were dissolved in Opti-MEM serum-free media (\#11058-021, Life Technologies, Carlsbad, CA). The BECN1 or scrambled siRNA were delivered into the C2C12 cell cultures via Lipofectamine 2000 (\#11668-019, Invitrogen, Carlsbad, CA) that had been plated 24 hours prior (approximately 25\% confluency). The final concentration of BECN1 and scrambled siRNA in culture was $2 \mathrm{nM}$. The cells were incubated with the transfection reagents for 48 hours before harvest for analysis (approximately $80 \%$ confluency). 
Protein knockdown was assessed via Western blot analysis as follows: Approximately $2 \times 10^{6}$ cells were harvested and collected from each C2C12 BECN1 siRNA- or scrambled controltreated culture. Cells were washed twice with PBS and resuspended in $0.4 \mathrm{~mL}$ PBS before mechanical homogenization with a dounce homogenizer. A BCA assay (\#23225, Pierce/Thermo Fisher Scientific, Waltham, MA) was used to determine protein amounts. The protein homogenates were denatured 1:1 in Laemmli buffer (\#1610737, Bio-Rad, Hercules, CA) with 5\% beta-mercaptoethanol (\#M6250-100ML, Sigma-Aldrich, St. Louis, MO) by incubating at $100^{\circ} \mathrm{C}$ for 10 minutes. Approximately $2.5-5 \mu \mathrm{g}$ of each sample were loaded unto a $12.5 \%$ Criterion $^{\mathrm{TM}}$ Tris- $\mathrm{HCl}$ gel (\#3450014, Bio-Rad, Hercules, CA) and the proteins separated by running at $150 \mathrm{~V}$ for 50 minutes. The proteins were transferred to a nitrocellulose membrane (\#162-0235, Bio-Rad, Hercules, CA) overnight at $500 \mathrm{~mA}$ at $4^{\circ} \mathrm{C}$. The membranes were blocked in a $5 \%$ skim milk in TBS/T solution and then washed 3 times with TBS/T. The rabbit-hosted Beclin-1 (\#NB500-249, Novus Biologicals/Bio-Techne, Minneapolis, MN) and rabbit-hosted GAPDH (\#600-401-A33, Rockland Immunochemicals, Pottstown, PA) were used as primary antibodies (GAPDH used as a loading control) in 1:2000 and 1:5000 antibody dilutions, respectively. After an overnight incubation with the primary antibodies overnight at $4^{\circ} \mathrm{C}$, the membranes were washed 3 times with TBS/T and then incubated with goat anti-rabbit HRPconjugated IgG secondary antibody (\#G21234, Invitrogen, Eugene, OR) at $1: 10,000$ and 1:15,000 dilutions for the Bec1 and GAPDH-probed membranes, respectively, for 1 hour at room temperature. The membranes were washed 3 more times in TBS/T and treated with Supersignal West Femto Maximum Sensitivity Substrate (\#34095, Thermo Fisher Scientific, Waltham, MA) according to manufacturer's instructions. Blots were imaged onto films using a Konica Minolta SRX-101A developer. A similar procedure was employed for performing ATG5 and ATG7 knockdowns. While ATG5 and ATG7 knockdowns resulted in approximately $70 \%$ reduction in the corresponding protein levels, we were unable to detect the BECN1 protein using the rabbit-hosted Beclin-1 antibody described above. Hence we were unable to establish 
the level of knockdown in the $\mathrm{C} 2 \mathrm{C} 12$ cells used here. However, it should be noted that BECN1 Silencer $^{\circledR}$ Select Pre-designed siRNAs have been used by other investigators to successfully knockdown BECN1.2, 3

\section{Kinetic Constant Measurement}

His-tagged rat FTase (rFTase) was expressed in E. coli and purified similarly to previous methods. ${ }^{4}$ The rate of farnesylation of purified peptide by rFTase was determined using the time-dependent increase in fluorescence $\left(\lambda_{\text {ex }} 340 \mathrm{~nm}, \lambda_{\mathrm{em}} 505 \mathrm{~nm}\right)$ upon prenylation of a dansylated form of the peptide. Assays were performed with $2.0 \mu \mathrm{M}$ dansyl-GlyCysValLeuSer (Ds-GCVLS), $20 \mathrm{nM}$ rFTase, varying concentrations $(0.25-16 \mu \mathrm{M})$ of FPP/alkyne analogue, 50 $\mathrm{mM}$ Tris, $\mathrm{pH}$ 7.5, $5 \mathrm{mM}$ DTT, $5 \mathrm{mM} \mathrm{MgCl} 2,50 \mu \mathrm{M} \mathrm{ZnCl}$, and $0.040 \%(w / v) n$-dodecyl- $\beta$-Dmaltoside at $25^{\circ} \mathrm{C}$. Peptides were incubated in reaction buffer for 5 min prior to initiation by the addition of rFTase. Fluorescence was measured as a function of time to define both the initial linear velocity and the reaction end point on a Varian Cary Eclipse Fluorescence Spectrophotometer. The total fluorescence change observed upon reaction completion was

divided by the initial concentration of the peptide substrate in a given reaction to yield a conversion from fluorescence units to product concentration $\left(\mathrm{Amp}_{\mathrm{conv}}\right)$. The linear initial rate, $\mathrm{V}$, in fluorescence intensity per minute, was then converted to a velocity ( $\mu \mathrm{M}$ product produced per minute) by dividing $\mathrm{V}$ with $\mathrm{Amp}_{\text {conv. }}$

\section{Western Blot Analysis}

Cell lysates were prepared using the following buffer: $50 \mathrm{mM}$ Tris- $\mathrm{HCl}, \mathrm{pH} 7.4,1 \% \mathrm{NP}-40$, 0.25\% Na-deoxycholate, $150 \mathrm{mM} \mathrm{NaCl}, 1 \mathrm{mM}$ EDTA, $1 \mathrm{mM} \mathrm{PMSF,} 1 \mathrm{mg} \mathrm{mL}^{-1}$ aprotinin, $1 \mathrm{mg}$ $\mathrm{mL}^{-1}$ leupeptin, $1 \mathrm{mM} \mathrm{Na} \mathrm{VO}_{4}, 1 \mathrm{mM} \mathrm{NaF}, 20 \mathrm{mM}$ b-glycerophosphate. Lysates were cleared by centrifugation $\left(16,000 \times \mathrm{g}, 10 \mathrm{~min}, 4^{\circ} \mathrm{C}\right)$ and proteins $(40 \mu \mathrm{g})$ were resolved using $15 \%$ SDS- 
polyacrylamide mini-gels, and then transferred to Immobilon-P PVDF membrane. After blocking in a TBST/5\% milk solution, immunoblots were incubated overnight at $4{ }^{\circ} \mathrm{C}$ using the following primary antibodies: anti-H-ras rabbit polyclonal (1:500) and anti-ERK2 rabbit polyclonal (1:2000), see Materials section for manufacturers. Following this, the membranes were incubated with an anti-rabbit IgG horseradish peroxidase-linked secondary antibody. The immunoblots were visualized using the SuperSignal West Pico Chemiluminescent Substrate following manufacturers protocols.

\section{TAMRA-PEG- $\underline{N}_{3}$ synthesis}

TAMRA-PEG- $\mathrm{N}_{3}$ was synthesized similar to a previously described method. ${ }^{5}$ TAMRAsuccinimidyl ester $(25.0 \mathrm{mg}, 47.4 \mu \mathrm{mol})$ was dissolved in $0.4 \mathrm{~mL} N, N$-dimethylformamide (DMF). To this solution, 11-Azido-3,6,9-trioxaundecan-1-amine $(14.1 \mu \mathrm{L}, 71.1 \mu \mathrm{mol})$ and diisopropylethylamine $(4.1 \mu \mathrm{L}, 23.7 \mu \mathrm{mol})$ were added. The reaction was stirred overnight at RT in the dark. The reaction was diluted with 10 volumes of $0.1 \%$ aqueous TFA, filtered through a $0.2 \mu \mathrm{m}$ syringe filter, and purified by RP-HPLC on a $\mathrm{C}_{18}$ column using a gradient of $1 \% \mathrm{~B}$ per minute (solvent $A: 0.1 \%$ aqueous trifluoroacetic acid (TFA), solvent $B: 0.1 \%$ TFA in $\mathrm{CH}_{3} \mathrm{CN}$ ), affording a dark red solid. Yield: $15.6 \mathrm{mg}(52.1 \%)$, product eluted at $36 \% \mathrm{CH}_{3} \mathrm{CN}$. Deconvoluted ESI-MS calculated for $\mathrm{C}_{33} \mathrm{H}_{39} \mathrm{~N}_{6} \mathrm{O}_{7}=631.3$, found 631.3.

\section{Farnesyl alkyne synthesis}

Farnesol (3.00 g, $13.5 \mathrm{mmol})$ was dissolved in dry THF $(15.0 \mathrm{~mL})$. The mixture was placed under argon and cooled to $0^{\circ} \mathrm{C}$. $\mathrm{NaH}(0.48 \mathrm{~g}, 20.2 \mathrm{mmol})$ was slowly added to the flask. The mixture was stirred at $0{ }^{\circ} \mathrm{C}$ for $45 \mathrm{~min} .80 \%$ propargyl bromide in toluene $(9.0 \mathrm{~mL}, 81 \mathrm{mmol})$ was added to this mixture dropwise and it was stirred at $0{ }^{\circ} \mathrm{C}$ for $1 \mathrm{~h}$. The solution was warmed to room temperature slowly and stirred at room temperature for $16 \mathrm{~h}$, after which point water was 
added to quench the reaction. The solution was extracted with diethyl ether $(3 \times)$. The combined organic layers were dried with $\mathrm{MgSO}_{4}$ and concentrated in vacuo. The resulting brown oil was purified by flash chromatography ( $3: 1$ hexanes/ethyl acetate) to yield farnesyl alkyne as a light brown oil (1.62 g, 46\%). 


\section{Supplementary data}

Table S1. Kinetic constants for the rPFTase-catalyzed reaction of FPP and analogues with Ds-GCVLS peptide.

\begin{tabular}{|l|l|l|l|}
\hline Isoprenoid & $\mathrm{k}_{\text {cat }}\left(\mathrm{s}^{-1}\right)^{\mathrm{a}}$ & $K_{\mathrm{M}}(\mu \mathrm{M})^{\mathrm{a}}$ & $\mathrm{k}_{\text {cat }} / K_{\mathrm{M}}($ rel. $)$ \\
\hline FPP $^{\mathrm{b}}$ & $0.21 \pm 0.01$ & $0.11 \pm 0.03$ & 1.0 \\
\hline C15Alk-OPP & $0.08 \pm 0.004$ & $0.14 \pm 0.06$ & 0.31 \\
\hline
\end{tabular}

${ }^{\mathrm{a}}$ These values were measured at a single peptide concentration and are hence apparent constants.

${ }^{\mathrm{b}}$ These values measured for FPP are comparable to previously published values. ${ }^{6,7}$
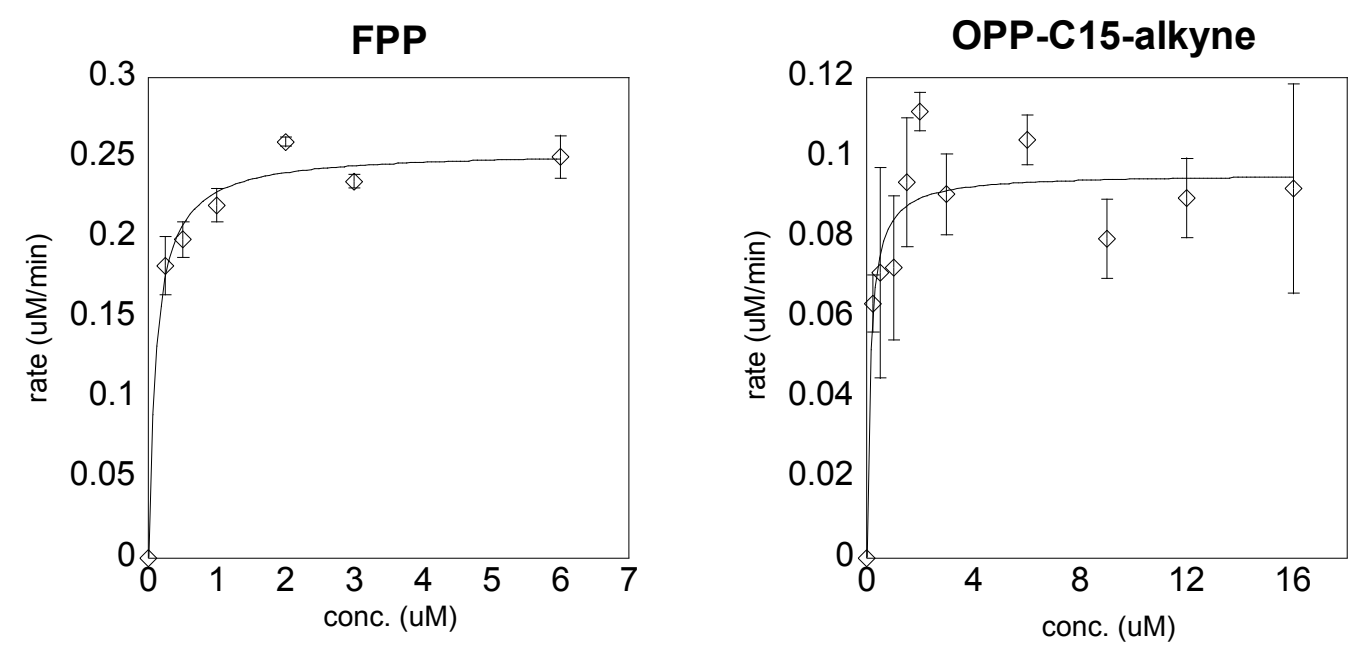

Figure S1. Fluorescence-based enzyme assay for prenylation using varying concentrations of FPP and C15Alk-OPP. Experiments were performed using a Varian model Cary Eclipse Fluorescence Spectrophotometer. The fluorescence detector was set at $340 \mathrm{~nm}$ and $505 \mathrm{~nm}$ for excitation and emission, respectively. Slit widths for excitation and emission were at $10 \mathrm{~nm}$ and at $10 \mathrm{~nm}$, respectively.

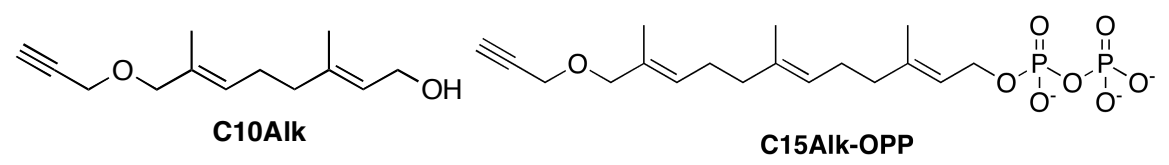

Figure S2. Structures of C10Alk and C15Alk-OPP. 

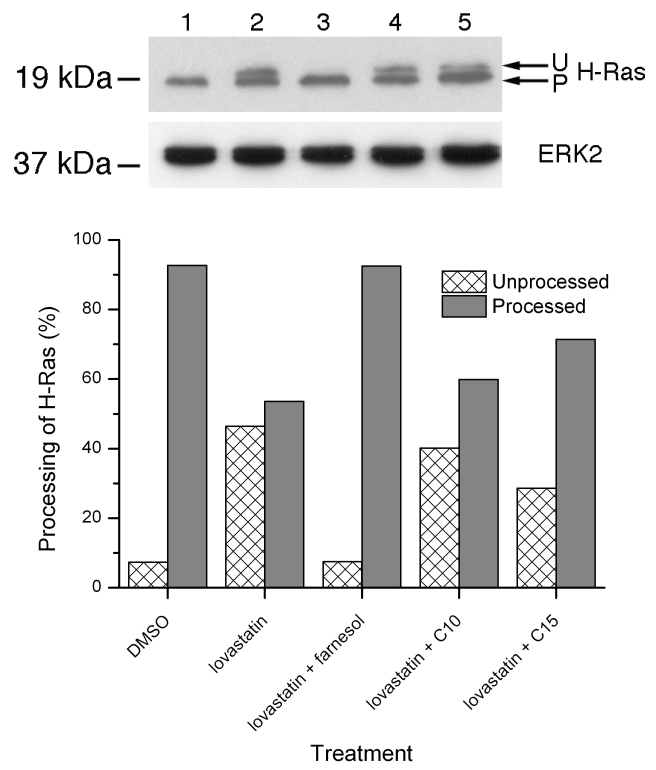

Figure S3. Top: Incorporation of C10Alk and C15Alk into H-Ras in COS-1 cells. COS-1 cells were treated with either DMSO $(0.05 \% \mathrm{v} / \mathrm{v}$, lane 1), $25 \mu \mathrm{M}$ lovastatin (lane 2), $25 \mu \mathrm{M}$ lovastatin and $100 \mu \mathrm{M}$ farnesol (lane 3), $25 \mu \mathrm{M}$ lovastatin and $100 \mu \mathrm{M}$ C10Alk (lane 4), or $25 \mu \mathrm{M}$ lovastatin and $100 \mu \mathrm{M}$ C15Alk (lane 5). After $24 \mathrm{~h}$, whole cell lysates were prepared and $40 \mu \mathrm{g}$ of protein was resolved by $15 \%$ SDS-PAGE. The proteins were transferred to a PVDF membrane and incubated with an antibody against $\mathrm{H}$-Ras. Note the faster mobility of processed Ras (P) compared with unprocessed Ras (U). Total ERK2 levels were measured as a loading control because they do not change in response to treatment with lovastatin or alkyne isoprenoids; Bottom: Densitometry analysis of western blot bands in Figure 2 using ImageJ.

a

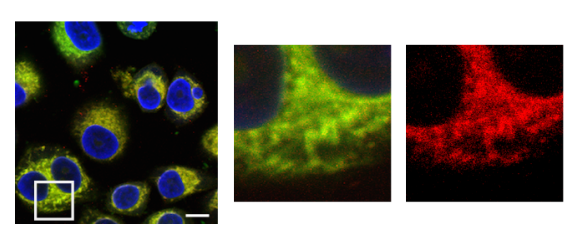

b

5-Fam Alexa Fluor 594 Merge
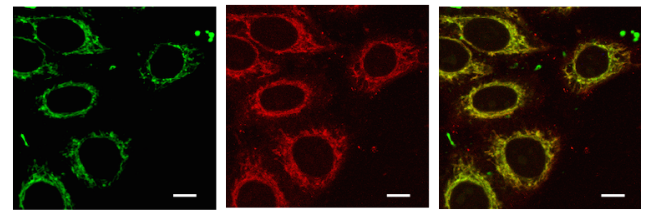

Figure S4. Imaging of prenylated proteins in mammalian cells via confocal microscopy indicates that a majority of C15Alk-labeled proteins localize in the endomembrane including the ER. Upon metabolic labeling (a. $10 \mu \mathrm{M}$ C15Alk for $24 \mathrm{~h}$; b. $25 \mu \mathrm{M}$ lovastatin overnight, then $10 \mu \mathrm{M} \mathrm{C15Alk}$ for $24 \mathrm{~h}$ ), cells were fixed and permeabilized. After several rinses, the cells were subjected to the CuAAC for $1 \mathrm{~h}$ with 5 -FamPEG- $\mathrm{N}_{3}$ and imaged using a $60 \mathrm{x}$ objective. The green channel shows prenylated proteins 'clicked' to 5Fam-PEG-N ${ }_{3}$, red channel showing staining of ER by ER Tracker Red. [Part a] Left: Overlay of images in green and red channels shown (same as panel $F$ in Figure 2 of the main text). Center: A zoomed in view (overlay of green and red channels) of the area marked by white box. Right: A zoomed in view of the area marked by white box showing only the ER Tracker Red labeling channel. This last image is provided to facilitate visualization of colocalization. [Part b] Merged image on the right shows colocalization of C15Alklabeled proteins in absence of lovastatin pre-treatment (left) with ER channel (center). 

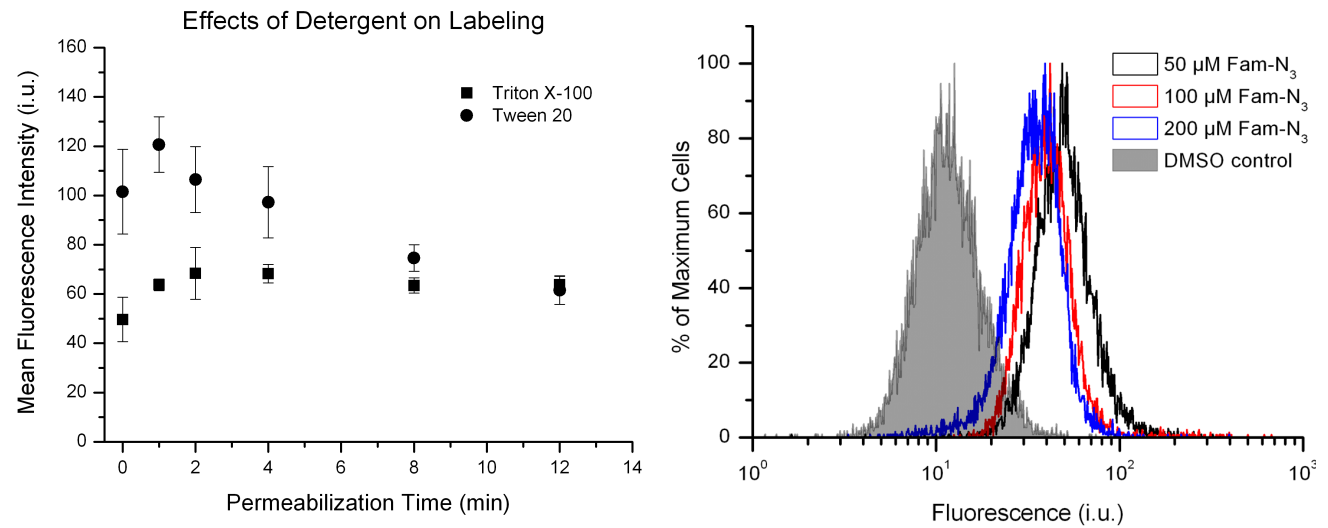

Figure S5. Establishing reaction conditions to label the prenylome in cells. HeLa cells were incubated with $50 \mu \mathrm{M}$ of C15Alk for $24 \mathrm{~h}$ and then fixed using paraformaldehyde. In A), cells were permeabilized using either Triton X-100 or Tween 20 for various lengths of times $(0-12 \mathrm{~min})$ and then subjected to the CuAAC with $50 \mu \mathrm{M}$ 5-Fam-PEG- $\mathrm{N}_{3}$ for $1 \mathrm{~h}$. An incubation time of 2 min with $0.1 \%$ Triton X-100 in PBS was found to be optimum. In B), cells were permeabilized using Triton X-100 (2 min at RT) and subjected to CuAACs with indicated concentrations of 5 -Fam-PEG- $\mathrm{N}_{3}$ for $1 \mathrm{~h}$. After several additional rinses, the cells were analyzed by flow cytometry and the results are expressed as the percentage of maximum cell count. Data were obtained in triplicate with similar results. $50 \mu \mathrm{M}$ 5-Fam-PEG-N ${ }_{3}$ was found to be sufficient to cause significant labeling over background.

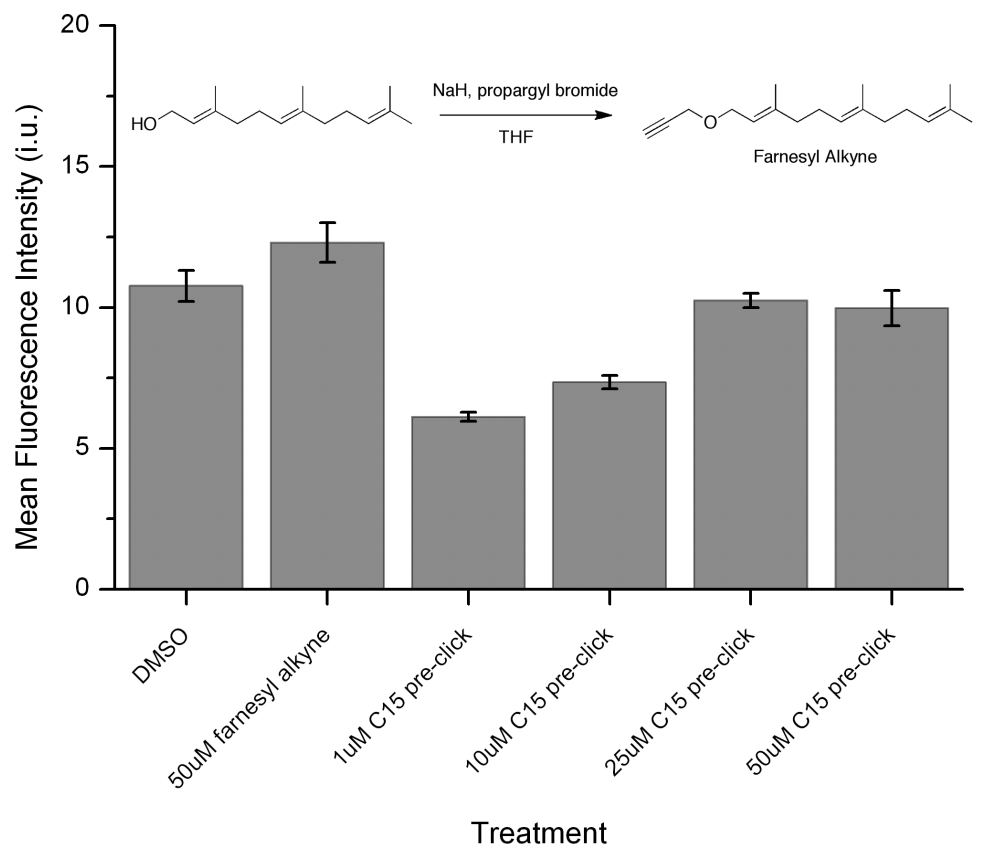

Figure S6. Control experiments utilizing a non-reactable farnesyl alkyne analog demonstrate no background labeling. Farnesyl alkyne was incubated with HeLa cells at $50 \mu \mathrm{M}$ for $24 \mathrm{~h}$ followed by fixation, permeabilization, and the CuAAC to 5-Fam-PEG- $\mathrm{N}_{3}$. The extent of the prenylated protein labeling with this analog is not over the DMSO background, as this analog is not capable of being incorporated onto proteins as it lacks the ability to be phosphorylated. Further, C15Alk at various concentrations was incubated with 5-Fam-PEG- $\mathrm{N}_{3}$ in vitro prior to cellular incubation ('C15 pre-click'). This 'pre-clicked' mixture was then added to fixed cells for $1 \mathrm{~h}$, followed by washing and analysis by flow cytometry. The labeling in all cases is less than the DMSO background, indicating that the fluorophore-isoprenoid complex that is formed during the CuAAC isn't being trapped or non-specifically attached to the cells and causing background labeling. 


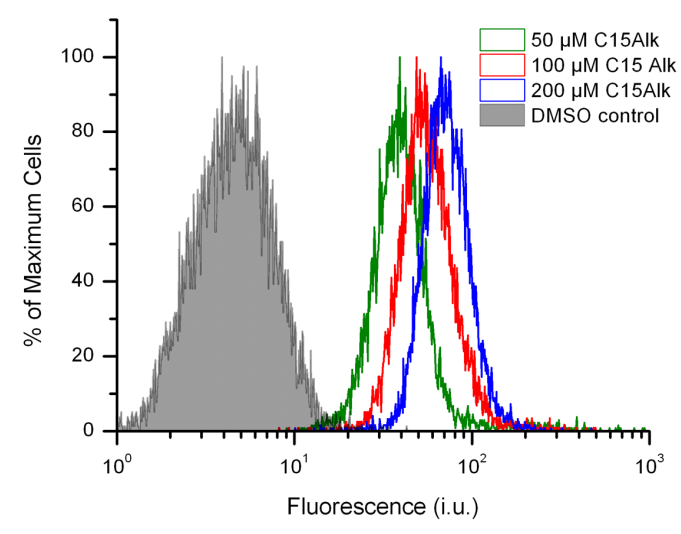

Figure S7. Establishing conditions for metabolic labeling of prenylated proteins. HeLa cells were incubated with various concentrations of C15Alk for $24 \mathrm{~h}$. The cells were then fixed, permeabilized for 2 min, rinsed, and subjected to the CuAAC with $50 \mu \mathrm{M}$ 5-Fam-PEG- $\mathrm{N}_{3}$ for $1 \mathrm{~h}$. After several additional rinses, the cells were analyzed by flow cytometry and the results are expressed as the percentage of maximum cell count. In both cases the data was obtained in triplicate with similar results.
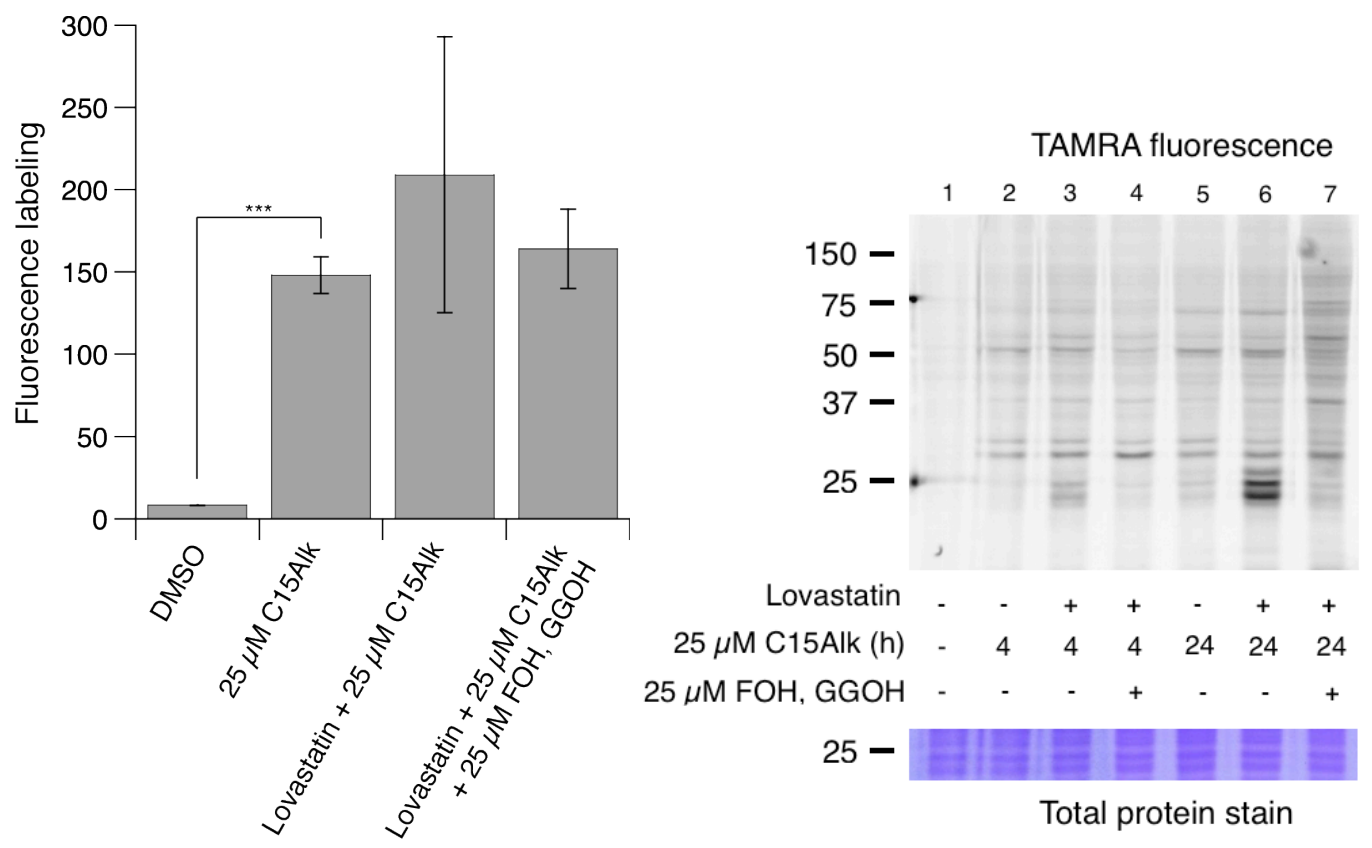

Figure S8. Farnesol and geranylgeraniol do not decrease overall incorporation of 25 or $50 \mu \mathrm{M} \mathrm{C15Alk} \mathrm{in}$ HeLa cells. Left: HeLa cells were pre-treated with $25 \mu \mathrm{M}$ lovastatin for $24 \mathrm{~h}$ and then labeled with $25 \mu \mathrm{M}$ C15Alk for $4 \mathrm{~h}$, in the presence or absence of $25 \mu \mathrm{M}$ farnesol (FOH) and geranylgeraniol (GGOH); right: HeLa cells were pre-treated with $25 \mu \mathrm{M}$ lovastatin for $24 \mathrm{~h}$ and then labeled with $25 \mu \mathrm{M} \mathrm{C15Alk}$ for $4 \mathrm{~h}$, in the presence or absence of $25 \mu \mathrm{M}$ farnesol $(\mathrm{FOH})$ and geranylgeraniol $(\mathrm{GGOH})$. Cells were then fixed, permeabilized and subjected to CuAACs with the indicated concentrations of 5-Fam-PEG- $\mathrm{N}_{3}$ for $1 \mathrm{~h}$. The cells were analyzed via flow cytometry and the results are expressed as the mean fluorescence intensity of 10,000 cells \pm standard error of the mean of at least three replicates. 

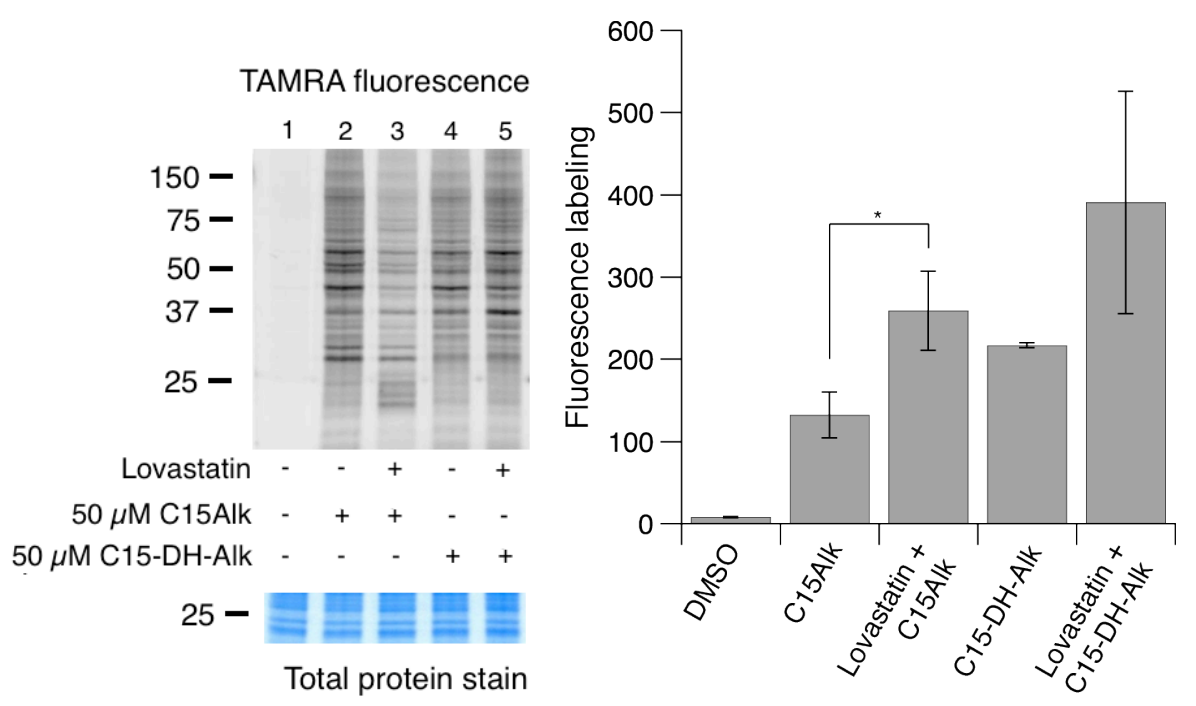

Figure S9. Incorporation of C15-DH-Alk in HeLa cells is independent of lovastatin treatment. HeLa cells were treated with $50 \mu \mathrm{M}$ of C15Alk or C15-DH-Alk, in presence or absence of pre-treatment with $25 \mu \mathrm{M}$ lovastatin. Left: Cells were lysed, and lysates were reacted with $25 \mu \mathrm{M}$ of TAMRA-PEG- $\mathrm{N}_{3}$ for $1 \mathrm{~h}$ and then proteins were separated on a $12 \%$ polyacrylamide gel. Right: Cells were then fixed, permeabilized and subjected to CuAACs with $50 \mu \mathrm{M}$ of 5 -Fam-PEG- $\mathrm{N}_{3}$ for $1 \mathrm{~h}$. The cells were analyzed via flow cytometry and the results are expressed as the mean fluorescence intensity of 10,000 cells \pm standard error of the mean of at least three replicates.
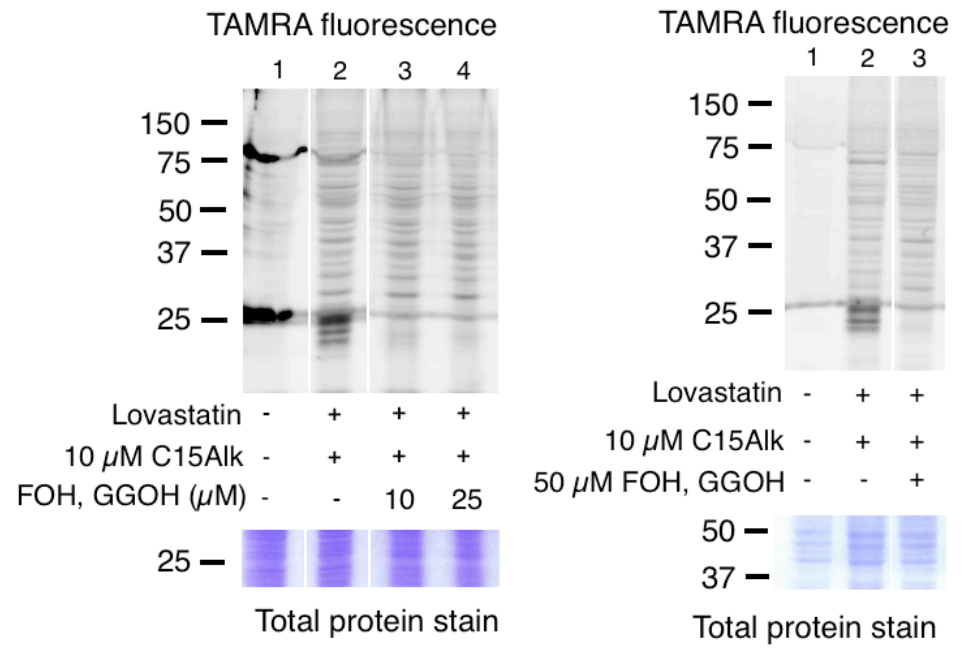

Figure S10. 10-50 $\mu \mathrm{M} \mathrm{FOH}$ and GGOH significantly compete away labeling caused by $10 \mu \mathrm{M} \mathrm{C15Alk,}$ particularly in $25 \mathrm{kDa}$ region. HeLa cells were treated for $24 \mathrm{~h}$ with $10 \mu \mathrm{M} \mathrm{C15}$, in the presence or absence of $10 \mu \mathrm{M}$ C15Alk overnight pre-treatment. 10, 25 or $50 \mu \mathrm{M}$ farnesol and geranylgeraniol, each, were added simultaneously with C15Alk to compete away cellular labeling of prenylated proteins. Cells were lysed, and lysates were reacted with $25 \mu \mathrm{M}$ of TAMRA-PEG- $\mathrm{N}_{3}$ for $1 \mathrm{~h}$ and then proteins were separated on a $12 \%$ polyacrylamide gel. Densitometry analysis of these images included in Figure 6. 

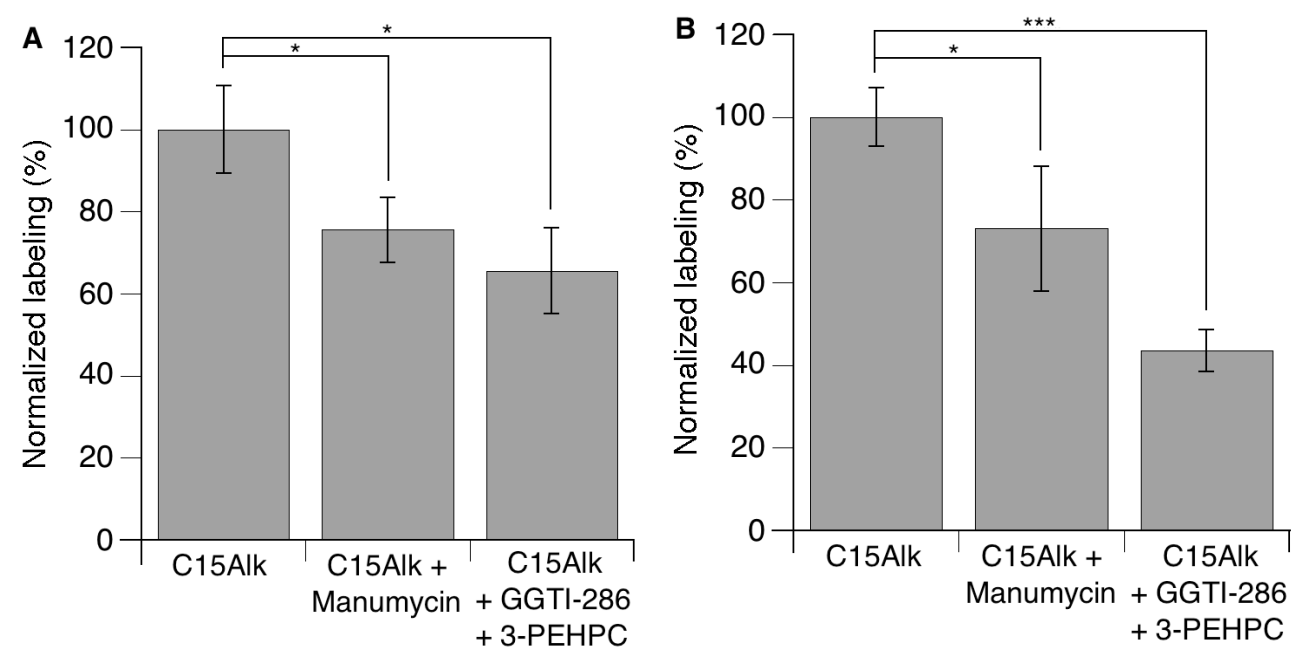

C TAMRA fluorescence
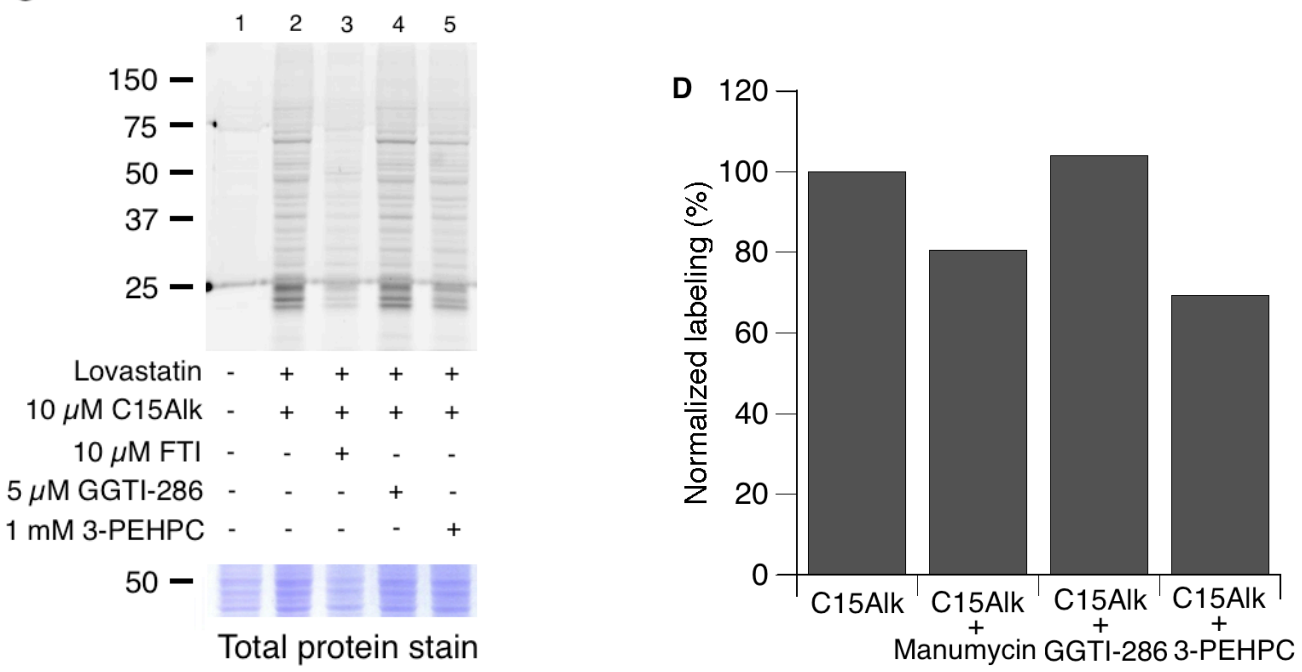

Figure S11. Quantitation of the effects of prenyltransferase inhibitors on the metabolic incorporation of C15Alk. HeLa cells (A, C, D) and COS-7 cells (B) were treated overnight with $25 \mu \mathrm{M}$ lovastatin, and then incubated with prenyltransferase inhibitors for $1 \mathrm{~h}$. Inhibitors treatments consisted of $15 \mu \mathrm{M}$ Manumycin (inhibitor of FTase, FTI), $5 \mu \mathrm{M}$ GGTI-286 (GGTase-I inhibitor) and $1 \mathrm{mM}$ 3-PEHPC (GGTase-II inhibitor). $10 \mu \mathrm{M} \mathrm{C15Alk}$ was then added to cells and cells were labeled for $24 \mathrm{~h}$ (in presence of inhibitors). A, B: Cells were then fixed, permeabilized and subjected to CuAACs with the indicated concentrations of 5Fam-PEG- $N_{3}$ for $1 \mathrm{~h}$. The cells were analyzed via flow cytometry and the results are expressed as the mean fluorescence intensity of 10,000 cells \pm standard error of the mean of at least three replicates. C: Cells were lysed, and lysates were reacted with $25 \mu \mathrm{M}$ of TAMRA-PEG- $\mathrm{N}_{3}$ for $1 \mathrm{~h}$ and then proteins were separated on a $12 \%$ polyacrylamide gel. D: Densitometry analysis of the gel image in panel C. 

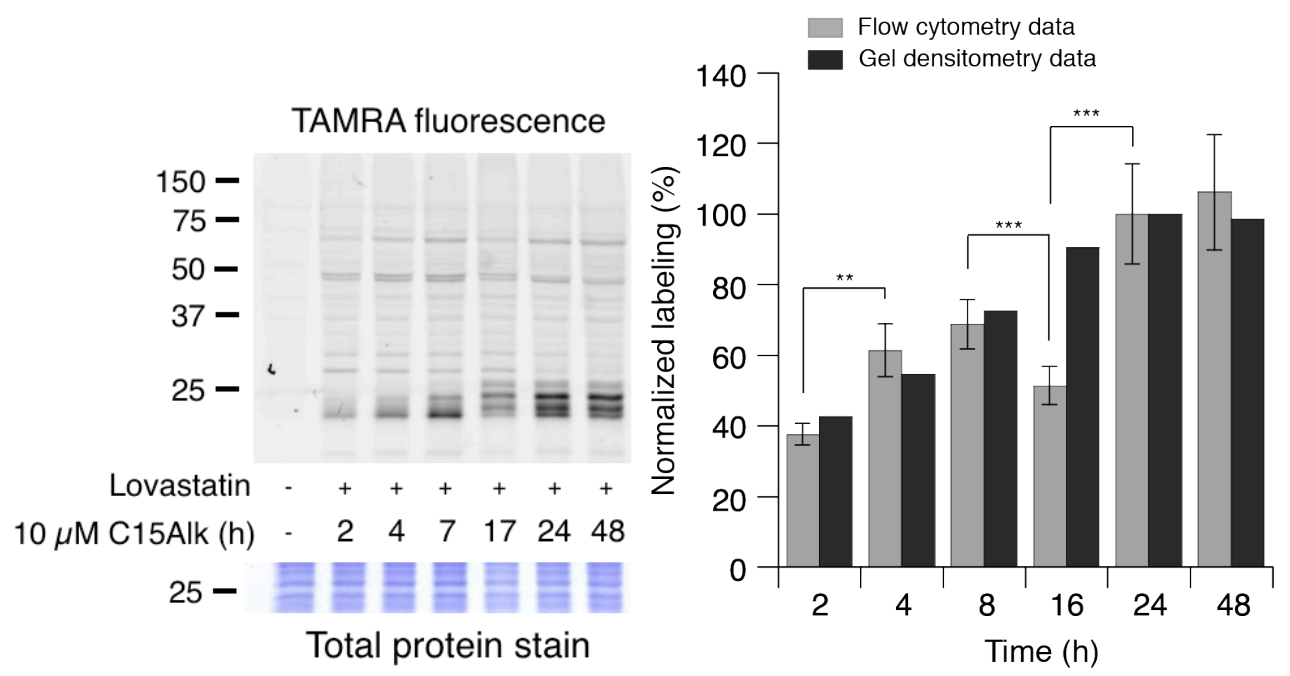

Figure S12. Incorporation kinetics of $10 \mu \mathrm{M}$ C15Alk in HeLa cells studied by flow cytometry and in-gel fluorescence analysis. HeLa cells were treated overnight with $25 \mu \mathrm{M}$ lovastatin. Cell media was then replaced with media containing $10 \mu \mathrm{M} \mathrm{C15Alk}$, and cells were incubated for the 2-48 h. Densitometry measurements of in-gel fluorescence image were performed using ImageJ and graphed against in situ analysis via flow cytometry of similarly treated cells, subjected to the flow cytometry quantification described above. The results are displayed as the normalized maximum fluorescence labeling in which each sample was divided by the maximum value to give a percentage of fluorescent labeling. Both sets of data have been background subtracted and the densitometry data is normalized to the total protein stain.

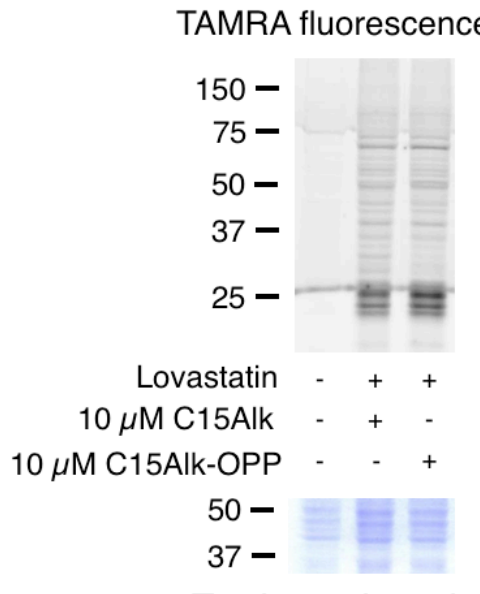

Total protein stain

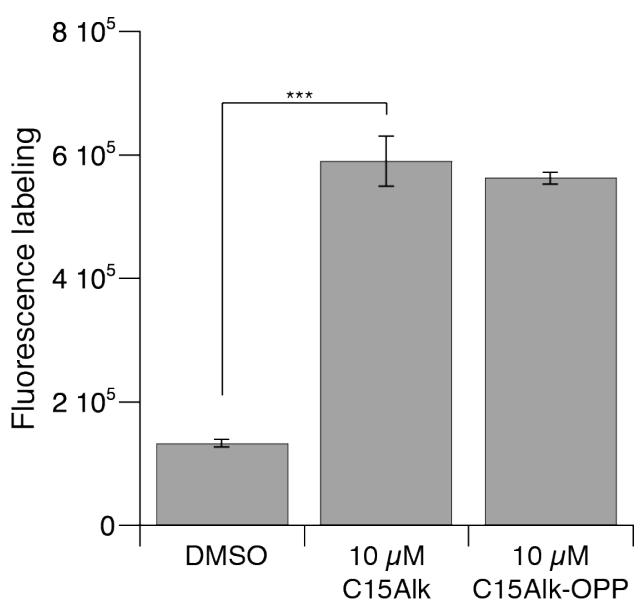

Figure S13. Extent and pattern of incorporation of C15Alk-OH and C15Alk-OPP in HeLa cells is similar. HeLa cells were pre-treated with $25 \mu \mathrm{M}$ lovastatin and then labeled with $10 \mu \mathrm{M}$ C15Alk or C15Alk-OPP for $24 \mathrm{~h}$. Left: Cells were lysed, and lysates were reacted with $\mu \mathrm{M}$ of TAMRA-PEG- $\mathrm{N}_{3}$ for $1 \mathrm{~h}$ and then proteins were separated on a $12 \%$ polyacrylamide gel. Right: Cells were then fixed, permeabilized and subjected to CuAAC with $50 \mu \mathrm{M}$ of 5 -Fam-PEG-N ${ }_{3}$ for $1 \mathrm{~h}$. The cells were analyzed via flow cytometry and the results are expressed as the mean fluorescence intensity of 10,000 cells \pm standard error of the mean of at least three replicates. 

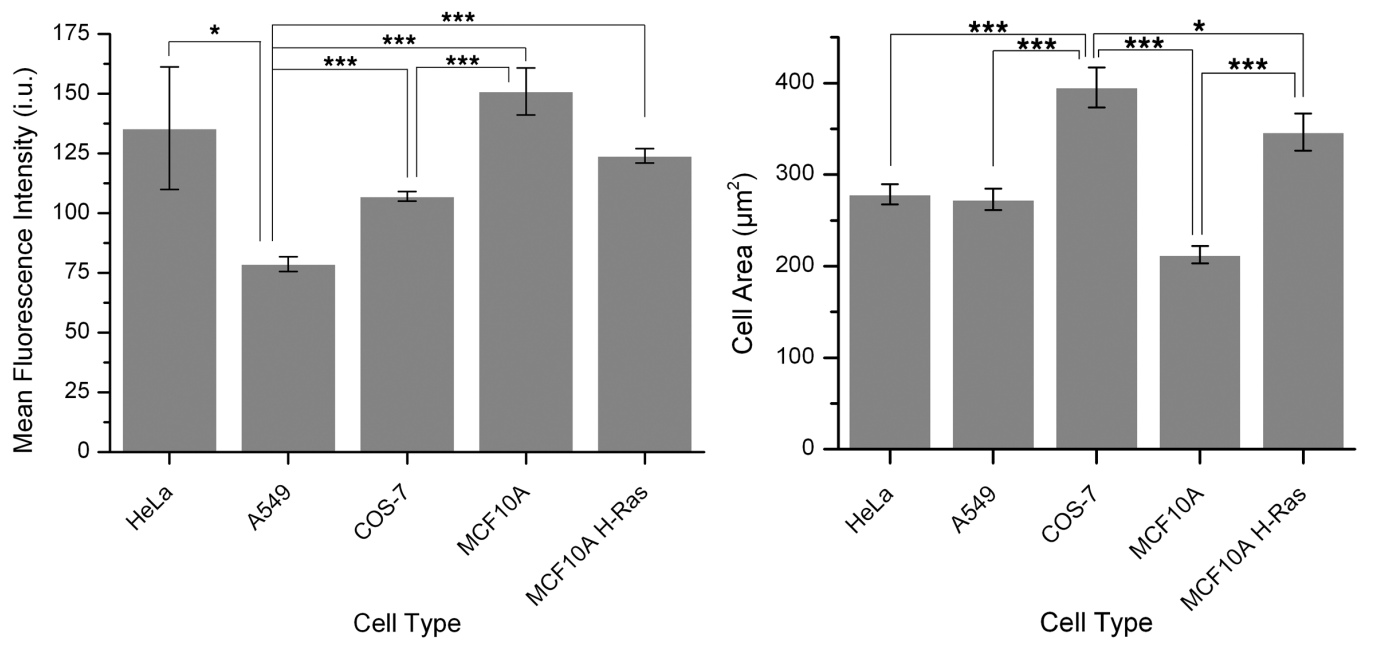

Figure S14. Extension of method to other cell lines. Left: Flow cytometry of various cell types that have been incubated with C15Alk at $50 \mu \mathrm{M}$ for $24 \mathrm{~h}$, followed by fixation, permeabilization, and the CuAAC to 5 -Fam- $\mathrm{N}_{3}$ for $1 \mathrm{~h}$. The results are expressed as the mean fluorescence intensity of 10,000 cells \pm standard error of the mean of at least three replicates. Right: The plasma membrane of various types of cells was stained with Wheat Germ Agglutinin-AlexaFluor 594 conjugate (following manufacturers protocols) and the area of the cell was calculated using ImageJ software. The results are expressed as the mean cell area \pm standard error of the mean of at least 40 measured cells. For statistical analysis, the Students t-test was performed assuming a one-tailed distribution and samples having equal variance. Results were considered significant if $p<0.05\left(^{*}\right), p<0.01\left(^{* *}\right)$, or $\left.p<0.001{ }^{* * *}\right)$.
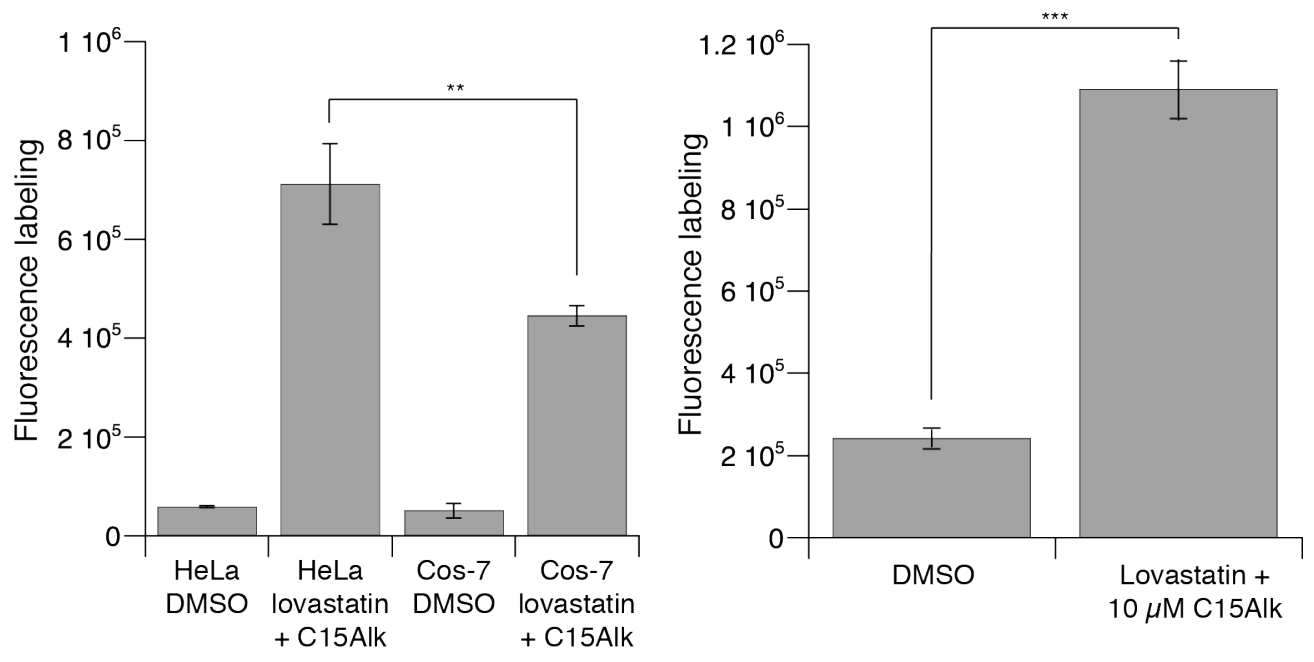

Figure S15. Metabolic labeling of prenylated proteins with C15Alk and subsequent CuAAC and flow cytometry analysis can be extended to cell lines other than HeLa cells. Left: HeLa and Cos-7 cells were pre-treated overnight with $25 \mu \mathrm{M}$ lovastatin and then labeled with $10 \mu \mathrm{M}$ C15Alk. Right: Primary glial astrocyte mixed cells were treated with $25 \mu \mathrm{M}$ lovastatin and $10 \mu \mathrm{M}$ C15Alk simultaneously. For both panels: Cells were fixed, permeabilized and subjected to CuAAC with $50 \mu \mathrm{M}$ of 5 -Fam-PEG- $\mathrm{N}_{3}$ for $1 \mathrm{~h}$. The cells were analyzed via flow cytometry and the results are expressed as the mean fluorescence intensity of 10,000 cells \pm standard error of the mean of at least three replicates. A. Cos-7 cells, which have higher cell area (see Figure S12), have less incorporation of C15Alk compared to HeLa cells. B. There is significant incorporation of C15Alk in primary astrocyte cells. 


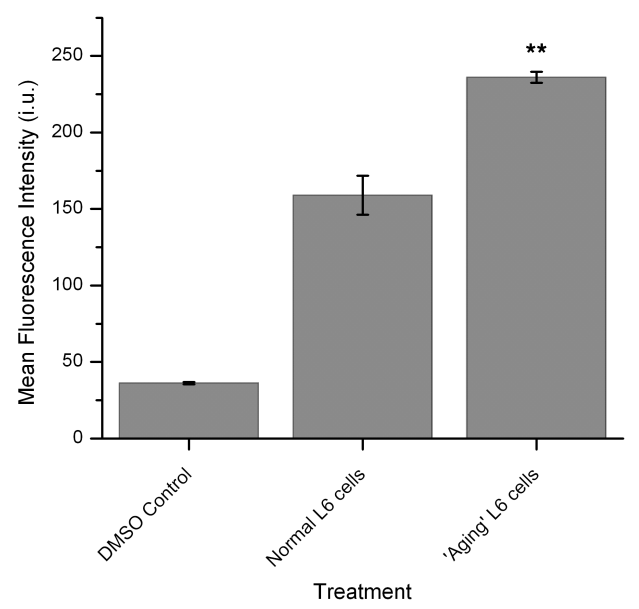

Figure S16. In a cellular model of compromised autophagy, a surrogate to study aging disorders, the levels of prenylated proteins are increased over normal control levels. In the defective autophagy cell model, the ATG7 gene controlling autophagy was knocked down with siRNA (denoted as "Aging" L6 cells). Control cells included transfection of a scrambled siRNA. After $24 \mathrm{~h}$ transfection period, cells were incubated with C15Alk at $50 \mu \mathrm{M}$ for $24 \mathrm{~h}$, followed by fixing, permeabilizing, and the CuAAC to 5-FamPEG- $\mathrm{N}_{3}$ and analysis by flow cytometry. After several additional rinses, the cells were analyzed by flow cytometry and the results are expressed as the mean fluorescence intensity of 10,000 cells \pm standard error of the mean of at least three replicates. There is a statistically significant $(p=0.002)$ increase in the amount of prenylated proteins in the model of compromised autophagy.

\section{References}

[1] Ochocki, J. D., Mullen, D. G., Wattenberg, E. V., and Distefano, M. D. (2011) Evaluation of a cell penetrating prenylated peptide lacking an intrinsic fluorophore via in situ click reaction, Bioorg. Med. Chem. Lett. 21, 4998-5001.

[2] Grkovic, S., O'Reilly, V. C., Han, S., Hong, M., Baxter, R. C., and Firth, S. M. (2013) IGFBP-3 binds GRP78, stimulates autophagy and promotes the survival of breast cancer cells exposed to adverse microenvironments, Oncogene 32, 2412-2420.

[3] Puustinen, P., Rytter, A., Mortensen, M., Kohonen, P., Moreira, J. M., and Jäättelä, M. (2014) CIP2A oncoprotein controls cell growth and autophagy through mTORC1 activation, J. Cell Biol. 204, 713-727.

[4] Hosokawa, A., Wollack, J. W., Zhang, Z., Chen, L., Barany, G., and Distefano, M. D. (2007) Evaluation of an alkyne-containing analogue of farnesyl diphosphate as a dual substrate for protein-prenyltransferases, Int. J. Pept. Res. Ther. 13, 345-354.

[5] Ochocki, J. D., Mullen, D. G., Wattenberg, E. V., and Distefano, M. D. (2011) Evaluation of a cell penetrating prenylated peptide lacking an intrinsic fluorophore via in situ click reaction, Bioorg. Med. Chem. Lett. 21, 4998-5001.

[6] Rawat, D. S., Krzysiak, A. J., and Gibbs, R. A. (2008) Synthesis and biochemical evaluation of 3,7-disubstituted farnesyl diphosphate analogues, J. Org. Chem. 73, 1881-1887.

[7] Subramanian, T., Pais, J. E., Liu, S., Troutman, J. M., Suzuki, Y., Subramanian, K. L., Fierke, C. A., Andres, D. A., and Spielmann, H. P. (2012) Farnesyl Diphosphate Analogues with Aryl Moieties Are Efficient Alternate Substrates for Protein Farnesyltransferase, Biochem. 51, 8307-8319. 